\title{
Myocardial viability in preserved or mildly impaired left ventricular function prior to revascularization - findings from a 3 year experience
}

\author{
Hannah Douglas ${ }^{1 *}$, Ben Cole ${ }^{1}$, Chin Munn Soong ${ }^{1}$, Paul Horan ${ }^{1}$, Lana Dixon ${ }^{1}$, Nicola Johnston ${ }^{1}$, Mark Harbinson ${ }^{2}$ \\ From 18th Annual SCMR Scientific Sessions \\ Nice, France. 4-7 February 2015
}

\begin{abstract}
Background
Viability testing prior to revascularization in ischaemic cardiomyopathy has courted controversy in the literature over recent years. Viability assessment prior to revascularization at our institution is largely requested for patients with severely impaired left ventricles (LV). This study however aims to review the outcomes of the patients with preserved or mildly impaired LV function who underwent cardiac magnetic resonance imaging (CMR) for viability assessment during consideration for revascularization and to evaluate its use in this group.
\end{abstract}

\section{Methods}

Patients undergoing CMR scans to assess viability prior to coronary artery revascularization were identified from January 2011 until June 2013. Demographics, viability and outcome data were collected for all.

\section{Results}

Viability assessments were undertaken in 256 patients who were referred for revascularization of coronary artery disease by either percutaneous or surgical methods. Of these patients $71(27.7 \%)$ were found to have preserved or mildly impaired LV function, defined by an ejection fraction greater than $45 \%$ (72\% male, mean age $66 \pm 12.8$ years). Adenosine stress perfusion was performed in $25.4 \%$. Ultimately $76 \%$ were revascularized (38\% underwent coronary artery bypass grafting (CABG) while $38 \%$ had percutaneous coronary intervention $(\mathrm{PCI})$ ). The remaining $24 \%$ were turned down for revascularization. The reason not to revascularize in $11.7 \%$ of cases was LAD territory nonviability. Other reasons were independent of the viability findings and included poor target vessels, co-morbidities and patient decision. Mean LV measurements within each group were as follows: ejection fraction CABG $56.67 \pm 7.58 \%$, PCI 57.41 $\pm 8.58 \%$, medical management $59.4 \pm 19.65 \%(\mathrm{p}=0.58)$ LVEDV CABG $87.74 \pm 19.37 \mathrm{mls}$, PCI $85.22 \pm 20.62 \mathrm{mls}$, medical management $80.41 \pm 16.14 \mathrm{mls}(\mathrm{p}=0.47)$. The number of non-viable segments within each group was: CABG $2.15 \pm 1.99$, PCI $2.15 \pm 2.13$ and medically managed $2.41 \pm 2.06(\mathrm{p}=0.90)$. The nonviable segments were in LAD territory in: CABG $22.2 \%$, PCI $33.3 \%$ and medical management $29.4 \%(\mathrm{p}=0.66)$. Median follow up was 2.4 years. Outcome data was as follows; MACE: CABG $14.8 \%$, PCI $7.4 \%$ and medical management $11.8 \%$ $(\mathrm{p}=0.69)$; death: CABG $11.1 \%$, PCI $7.4 \%$, with no reported deaths in the medical management group $(\mathrm{p}=0.37)$; revascularization: CABG $3.7 \%$, PCI $11.1 \%$ and medical management $11.8 \%(\mathrm{p}=0.53)$ and cardiac rehospitalisation: CABG 14.8\%, PCI $3.7 \%$ and medical management $11.8 \%(\mathrm{p}=0.37)$.

\section{Conclusions}

LV function and volume measurements and the number and territory of nonviable segments in preserved or mildly impaired left ventricular function was not significantly different between revascularized and medically managed patients. The rates of events or death did not differ significantly. Therefore CMR for viability assessment has not been shown to be a useful tool in guiding revascularization for patients with preserved or mildly impaired ventricles. We propose that stress perfusion without viability would improve the utility of CMR in this group of patients.

${ }^{1}$ Cardiology, Belfast Heart Centre, Belfast, UK

Full list of author information is available at the end of the article 


\section{Funding}

N/A.

\section{Authors' details}

${ }^{1}$ Cardiology, Belfast Heart Centre, Belfast, UK. ${ }^{2}$ Queen's University, Belfast, UK.

Published: 3 February 2015

doi:10.1186/1532-429X-17-S1-P133

Cite this article as: Douglas et al:: Myocardial viability in preserved or mildly impaired left ventricular function prior to revascularization findings from a 3 year experience. Journal of Cardiovascular Magnetic Resonance 2015 17(Suppl 1):P133.

Submit your next manuscript to BioMed Central and take full advantage of:

- Convenient online submission

- Thorough peer review

- No space constraints or color figure charges

- Immediate publication on acceptance

- Inclusion in PubMed, CAS, Scopus and Google Scholar

- Research which is freely available for redistribution

Submit your manuscript at www.biomedcentral.com/submit
C Biomed Central 